\title{
Erratum to: Isolated primary renal echinococcosis: a rare entity
}

\author{
Savitha Anil Kumar • Archana Shetty • \\ Chowdappa Vijaya $\cdot$ V. Geethamani
}

Published online: 9 May 2013

(C) Springer Science+Business Media Dordrecht 2013

\section{Erratum to: Int Urol Nephrol \\ DOI 10.1007/s11255-013-0402-6}

The author would like to correct the inadvertent error in the original publication of the article.

Under Discussion, the word 'cysts' in the third sentence of second paragraph should be replaced by 'hydatid embryo'.

The complete sentence is given below:

It is postulated that the hydatid embryo passes through the portal system into the liver and retroperitoneal lymphatics to reach the kidneys [2].

The online version of the original article can be found under doi:10.1007/s11255-013-0402-6.

S. Anil Kumar $(\bowtie) \cdot$ A. Shetty $\cdot$ C. Vijaya .

V. Geethamani

Department of Pathology, Sapthagiri Institute of Medical

Sciences and Research Center, Bangalore, Karnataka,

India

e-mail: savitha@kruthika.com 